\title{
RESPON MULTIPLIKASI ANGGREK BULAN (Phalaenopsis sp.) TERHADAP PENAMBAHAN BEBERAPA KONSENTRASI BAP (Benzyl Amino Purine) PADA MEDIA IN VITRO
}

\author{
Oleh: \\ Melissa Syamsiah*) \\ Angga Adriana Imansyah*) \\ Hana Khoerunisa Suprapti **) \\ Dedeh Siti Badriah***) \\ Email : melissasyamsiah@gmail.com
}

\begin{abstract}
Abstrak
Jenis anggrek yang paling banyak diminati dan dibudidayakan adalah anggrek bulan (Phalaenopsis sp.). Perbanyakan anggrek bulan dapat dilakukan dengan metode alternatif yang lebih efektif yaitu dengan melalui kultur in vitro. Tujuan penelitian adalah mengetahui pengaruh penambahan beberapa konsentrasi BAP (Bensyl Amino Purine) terhadap multiplikasi, waktu muncul tunas (HST), jumlah tunas, waktu muncul daun (MST), dan jumlah daun anggrek bulan (Phalaenopsis sp.). Penelitian dilakukan di Laboratorium Pemuliaan Kebun Percobaan Tanaman Hias Cipanas Balai Penellitian Tanaman Hias (BALITHI) dari bulan Februari - Mei 2020. Penelitian ini menggunakan Rancangan Acak Lengkap (RAL) dengan perlakuan beberapa konsentrasi BAP : B0 (0 mg/Liter), B1 (0,50 mg/Liter), B2 (1,00 $\mathrm{mg} /$ Liter), B3 (1,50 mg/Liter), B4 (2,00 mg/Liter). Hasil penelitian penambahan BAP berpengaruh positif terhadap waktu muncul tunas, waktu muncul daun dan jumlah daun tanaman anggrek. Penambahan BAP dengan konsentrasi $2,00 \mathrm{mg} / \mathrm{L}$ merupakan perlakuan paling baik. Sedangkan pengaruh terhadap parameter jumlah tunas tanaman anggrek bulan ditunjukkan oleh perlakuan penambahan BAP dengan konsentrasi $1,50 \mathrm{mg} / \mathrm{L}$.
\end{abstract}

Kata kunci : Anggrek bulan (Phalaenopsis sp.), Bensyl Amino Purine, Multiplikasi, media in vitro.

\section{Abstract}

The type of orchid that is most popular and cultivated is the moon orchid (Phalaenopsis sp.). Moon orchid propagation can be done by a more effective alternative method, namely through in vitro culture. The research objective was to determine the effect of adding several concentrations of BAP (Bensyl Amino Purine) on multiplication, shoot emergence time (HST), number of shoots, leaf emergence time (MST), and the number of leaves of the moon orchid (Phalaenopsis sp.). The research was conducted at the Cipanas Ornamental Plant Experimental Garden Breeding Laboratory, Indonesian Ornamental Plants Research Institute (BALITHI) from February - May 2020. This study used a completely randomized design (CRD) with several concentrations of BAP: BO (0 mg / Liter), B1 (0,50 mg / Liter), B2 (1.00 mg / Liter), B3 $(1.50 \mathrm{mg} / \mathrm{Liter}), B 4(2.00 \mathrm{mg} / \mathrm{Liter})$. The results of the research, the addition of BAP had a positive effect on shoot emergence time, leaf emergence time and the number of leaves of orchids. The addition of $B A P$ with a concentration of $2.00 \mathrm{mg} / \mathrm{L}$ is the best treatment. Meanwbile, the effect on the parameter of the number of shoots of the orchid plant was shown by the addition of BAP treatment with a concentration of $1.50 \mathrm{mg} / \mathrm{L}$.

Keywords: Moon orchid (Phalaenopsis sp.), BAP (Bensyl Amino Purine), Multiplication, in vitro media.

*) Dosen Fakultas Sains Terapan UNSUR.

**) Alumni Fakultas Sains Terapan UNSUR.

***) Peneliti Balai Penelitian Tanaman Hias (BALITHI) - Segunung Pacet Cianjur.

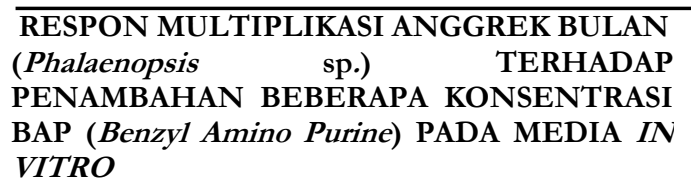

RESPON MULTIPLIKASI ANGGREK BULAN

PENAMBAHAN BEBERAPA KONSENTRASI VITRO
MELISSA SYAMSIAH, ANGGA ADRIANA IMANSYAH HANA KHOERUNISA SUPRAPTI dan DEDEH SITI BADRIAH 


\section{PENDAHULUAN}

Salah satu tanaman hias yang diminati masyarakat adalah tanaman anggrek, jenis anggrek yang paling banyak diminati dan dibudidayakan adalah anggrek bulan (Phalaenopsis sp.) (Indarto, 2011). Menurut Wu dan Chang (2009) data menunjukkan anggrek bulan adalah jenis anggrek yang memiliki penjualan terbesar di pasar dunia yakni dengan persentase penjualan $80 \%$. Jenis anggrek ini diminati karena memiliki waktu mekar yang lama dan tahan lama, yang bisa tahan mencapai waktu beberapa bulan. (Djajanegara, 2010).

Anggrek dapat diperbanyak secara konvensional melalui cara generatif dan vegetatif, generatif dilakukan dengan biji dan vegetatif dengan menggunakan stek, pemisahan rumpun dari batang. Kendala utama perbanyakaan anggrek secara konvensional adalah laju multiplikasi lambat dan memerlukan waktu yang lama (Martin dan Madassary, 2006). Perbanyakan anggrek bulan dapat dilakukan dengan metode alternatif yang lebih efektif yaitu dengan melalui kultur in vitro (kultur jaringan), dimana menurut Zulkarnaen (2009), kultur jaringan merupakan teknik isolasi bagian tanaman yang dipelihara dan ditumbuhkan pada media yang steril. Dalam teknik kultur jaringan ada salah satu tahapan yang terpenting yaitu tahapan multiplikasi. Multiplikasi adalah kegiatan memperbanyak calon tanaman dengan menanam eksplan pada media. Kegiatan ini dilakukan di laminar flow untuk menghindari adanya kontaminasi yang menyebabkan gagalnya pertumbuhan eksplan (Eshaflora, 2004).

Keberhasilan dalam teknik in vitro dipengaruhi oleh beberapa faktor diantaranya adalah media dengan penggunaan ZPT. Salah satu ZPT yang sering digunakan dalam campuran media kultur jaringan adalah BAP (Bensyl Amino Purine). BAP merupakan ZPT golongan sitokinin yang dapat mendorong pembelahan sel, membantu perkembangan embrio secara teratur, menghambat degradasi klorofil dan menghambat senescence (Panjaitan, 2005). Berdasarkan uraian di atas, maka penulis melakukan penelitian yang bertujuan untuk mengetahui pengaruh pemberian BAP pada media kultur jaringan serta bagaimana respon pertumbuhan planet anggrek bulan (Phalaenopsis sp.).

\section{METODE PENELITIAN}

\section{Waktu dan Tempat Penelitian}

Penelitian ini dilakukan di Laboratorium pemuliaan Kebun Percobaan Tanaman Hias Cipanas Balai Penellitian Tanaman Hias (BALITHI) dari bulan Februari - Mei 2020.

\section{Alat dan Bahan}

Dalam pelaksanaan penelitian ini penulis menggunakan beberapa alat dan bahan yang diperlukan. Alat yang digunakan yaitu timbangan analitik, labu erlenmeyer, gelas ukur, panci, kompor, botol atau jar, autoclave, $\mathrm{pH}$ meter, cawan petri, pisau skalpel, pinset, penjepit panjang, Laminar Air Flow, pembakar bunsen, karet, label, plastik wrap, plastik tahan panas, pengaduk dan magnetic stirrer.

Sedangkan bahan yang digunakan untuk penelitian ini terdiri dari eksplan Anggrek Bulan (Phalaenopsis sp.), Klon D 804-4, BAP (Bensyl Amino Purine), gula pasir, air kelapa, agar, dan larutan stok hara Murashige and Skoog (MS).

\section{Tahapan Penelitian \\ Pensterilan alat}

Alat disterilkan menggunakan autoclave, sebelum disterilkan alat seperti cawan petri, pisau scalpel, pinset, penjepit dicuci menggunakan sabun di air yang mengalir, setelah dicuci alat dikeringkan setelah kering alat dibungkus menggunakan kertas dan lapisi dengan plastik. Alat disterilkan pada suhu $121^{0}$ Celcius pada tekanan 1,5 atm selama 20 menit (Nugroho, 2004 dalam Paramartha et al., 2012). 


\section{Pembuatan Media}

Untuk membuat media digunakan beberapa bahan yaitu larutan stok yang mencakup unsur hara makro dan mikro, Vitamin, dan bahan tambahan seperti gula pasir, agar-agar, air kelapa, dan BAP sesuai dosis perlakuan. Takaran untuk masing-masing bahan untuk membuat media MS 1 liter yaitu :

1. MS : $4,43 \mathrm{mg} /$ liter

2. BAP : $0,50 \mathrm{mg} /$ liter, $1,00 \mathrm{mg} /$ liter, $1,50 \mathrm{mg} /$ liter

3. $\mathrm{NH}_{2} \mathrm{PO}_{4}: 0,12 \mathrm{mg} /$ Liter

4. Adenin Sulfat: $5 \mathrm{mg} /$ Liter

5. Peptone : $1 \mathrm{mg} /$ Liter

6. Agar-agar putih : 7 gram/liter

7. Air Kelapa : $150 \mathrm{ml} /$ liter

8. Gula pasir : 20 gram/liter

Bahan yang telah ditakar dimasukan ke labu erlenmeyer ditambahkan aquades sampai mencapai $1000 \mathrm{ml}$. Dicampur diatas magnetic stirer, setelah tercampur dituang ke dalam panci lalu dimasak dengan api sedang sampai mendidih. Selama memasak harus selalu diaduk agar tidak menggumpal. Setelah mendidih api dimatikan, media dituangkan ke dalam botol atau jar kultur sebanyak kurang lebih $50 \mathrm{ml}$ ditutup menggunakan plastik tahan panas kemudian disterilisasi menggunakan autoclave dengan suhu $121^{\circ} \mathrm{C}$ tekanan 2 atm selama 15 menit (Paramartha et.al, 2012). Setelah disterilisasi media disimpan diruang penyimpanan media.

\section{Penanaman Eksplan Anggrek Bulan}

Setelah media dibuat langkah selanjutnya adalah menanam ekaplan pada media yang telah disiapkan. Penanaman eksplan Anggrek Bulan dilakukan di dalam Laminar Air Flow (LAF), langkah pertama yaitu :

1. Lampu dan blower LAF dinyalakan. dan alat-alat seperti pisau skalpel, pinset, cawan petri, plastik warp dan label.

2. Blower dimatikan sebentar dan LAF di semprot alkohol $75 \%$ dan dilap sampai bersih, ketika dibersihkan blower kembali dinyalakan. Dan semua alatalat yang diperlukan dimasukan ke dalam LAF disterilkan dengan cara mencelup dalam larutan alkohol $100 \%$ dan diflamir di atas api bunsen.

3. Media yang telah disiapkan disemprot alkohol $70 \%$ dan dimasukan ke dalam LAF dilap menggunakan tissu steril.

4. Eksplan in vitro tunas anggrek diambil dengan pinset dan dipindahkan ke dalam cawan petri yang dialasi dengan tissu steril. Eksplan dibersihkan dari agar-agar sisa media sebelumnya, kemudian eksplan dipisahkan hingga beberapa bagian sekitar 7 atau 8 bagian dengan cara memotong dengan menggunakan pisau skalpel dan pinset. Masing-masing bagian tersebut ditanam di dalam botol kultur yang berisi media multiplikasi, satu botol berisi satu eksplan, setelah itu botol ditutup rapat dan dilapisi menggunakan plastik wrap dan diberi label.

\section{Inkubasi Kultur Anggrek Bulan}

Botol yang telah ditanami eksplan anggrek, kemudian diberi label yang memuat informasi jenis eksplan dan tanggal penanaman. Botol-botol kultur tersebut disusun di rak-rak kultur yang ada didalam ruangan inkubasi. Suhu yang baik dalam proses inkubasi adalah $24-25^{0}$ Celcius. Selama masa inkubasi pengamatan dilakukan setiap minggu sekali dan dicatat untuk diambil data pada minggu ke 2, 4, 6, 8, 10 dan 12 .

\section{Rancangan Percobaan}

Penelitian ini merupakan penelitian eksperimental. Parameter yang diamati dalam eksperimen ini adalah waktu muncul daun, jumlah daun, waktu muncul tunas, jumlah tunas, warna planlet, persentase eksplan hidup, mati dan terkontaminasi. Penelitian ini menggunakan Rancangan Acak Lengkap (RAL) dengan jumlah ulangan 5 kali dan setiap 1 botol sampel ditanami 3 eksplan Anggrek Bulan sehingga diperoleh 5 × $5=$ 
25 unit percobaan. perlakuan beberapa konsentrasi BAP sebagai berikut :

$$
\begin{array}{ll}
\text { B0 } & : 0 \mathrm{mg} / \text { Liter } \\
\text { B1 } & : 0,50 \mathrm{mg} / \text { Liter } \\
\text { B2 } & : 1,00 \mathrm{mg} / \text { Liter } \\
\text { B3 } & : 1,50 \mathrm{mg} / \text { Liter } \\
\text { B4 } & : 2,00 \mathrm{mg} / \text { Liter }
\end{array}
$$

\section{Parameter Pengamatan}

Parameter yang digunakan selama penelitian adalah sebagai berikut :

1. Waktu muncul tunas, diamati dan dicatat saat munculnya daun pada setiap planlet, dinyatakan dalam HST.

2. Jumlah tunas (buah). Daun yang terbentuk diamati pada usia 2, 4, 6, 8, 10 dan 12 minggu setelah penanaman, dengan cara menghitung jumlah tunas yang muncul pada setiap planlet.

3. Waktu muncul daun, diamati dan dicatat saat munculnya daun, dinyatakan dalam HST.

4. Jumlah daun (helai), daun yang terbentuk diamati pada usia 2, 4, 6, 8, 10 dan 12 minggu setelah tanaman.

\section{Analisis Data}

Data yang didapatkan dari hasil pengamatan akan dianalisis menggunakan bantuan Microsoft Exel dan Minitab. Penelitian ini dilakukan dengan menggunakan pola Rancangan Acak Lengkap (RAL). Data yang diperoleh dalam penelitian ini dianalisis menggunakan ANOVA. Jika terdapat perbedaan maka akan dilanjutkan dengan uji beda nyata antar perlakuan menggunakan uji Tukey pada taraf $5 \%$.

\section{HASIL DAN PEMBAHASAN}

\section{Waktu Muncul Tunas Anggrek Bulan (Phalaenopsis sp.)}

Waktu muncul merupakan salah satu indikator pertumbuhan yang menunjukan bahwa eksplan responsif terhadap treatment atau perlakuan yang diberikan. Waktu muncul tunas diamati setiap hari sejak awal penanaman hingga muncul tunas pertama. Hasil data secara statistik menunjukan bahwa perlakuan pemberian BAP, berpengaruh nyata terhadap waktu muncul tunas. Dapat dilihat pada Gambar1.

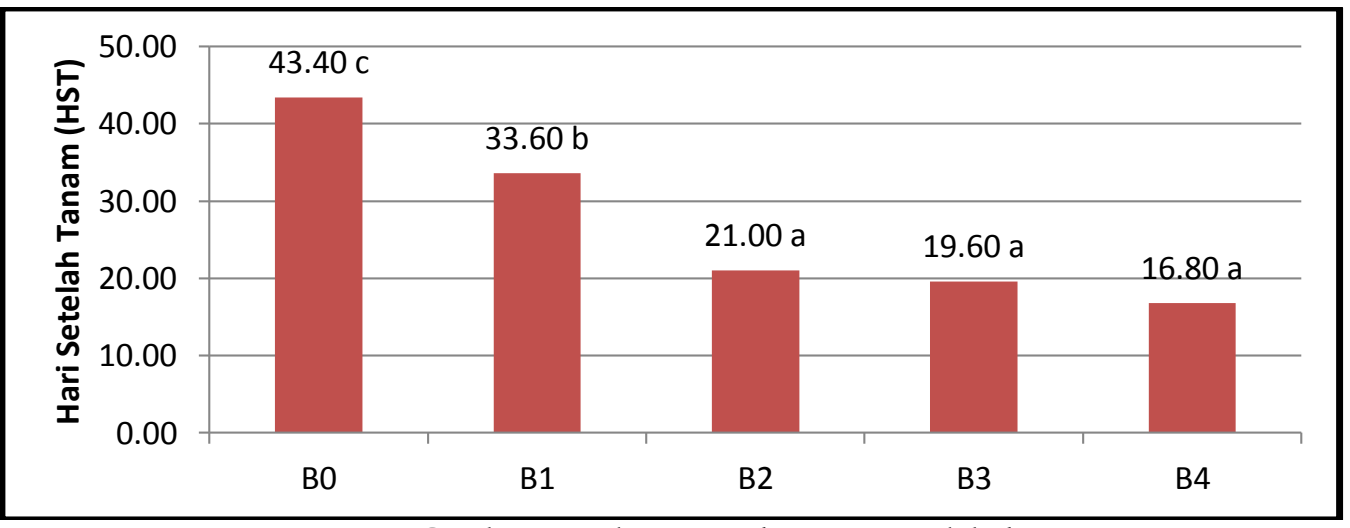

Gambar 1. Waktu muncul tunas anggrek bulan.

Keterangan : Angka yang diikuti dengan huruf yang sama pada grafik yang sama tidak berbeda nyata pada taraf 5\% dengan uji Tukey. B0 : Kontrol (Tanpa BAP), B1 : BAP konsentrasi 0,50 $\mathrm{mg} / \mathrm{L}, \mathrm{B} 2$ : BAP konsentrasi 1,00 mg/L, B3 : BAP konsentrasi 1,50 mg/L, dan B4 : BAP konsentrasi BAP 2,00 mg/L.

Berdasarkan Gambar 1 terlihat bahwa terdapat pengaruh dari penambahan beberapa konsentrasi BAP terhadap waktu muncul tunas. Dilihat dari diagram di atas waktu muncul tunas tercepat terdapat pada perlakuan B4 (konsentrasi $\mathrm{BAP}=2,00 \mathrm{mg} / \mathrm{L}$ ) dengan waktu muncul tunas tercepat dengan ratarata waktu muncul tunas 16,80 HST, perlakuan ini berbeda nyata dengan

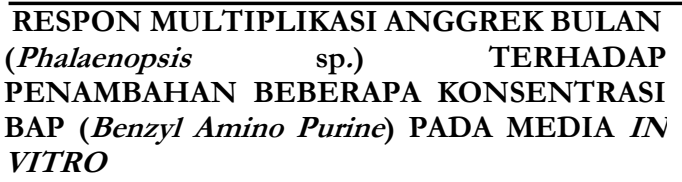

RESPON MULTIPLIKASI ANGGREK BULAN PENAMBAHAN BEBERAPA KONSENTRASI VITRO
MELISSA SYAMSIAH, ANGGA ADRIANA IMANSYAH HANA KHOERUNISA SUPRAPTI dan DEDEH SITI BADRIAH 
perlakuan B0 (kontrol/tanpa BAP), B1 (konsentrasi $\mathrm{BAP}=0,50 \mathrm{mg} / \mathrm{L}$ ), tetapi tidak berbeda nyata dengan perlakuan $\mathrm{B} 2$ (konsentrasi $\mathrm{BAP}=1,00 \mathrm{mg} / \mathrm{L}$ ) dan B3 (konsentrasi $\mathrm{BAP}=1,50 \mathrm{mg} / \mathrm{L}$ ). Hal ini diduga pemberian BAP yang merupakan ZPT golongan sitokinin berfungsi untuk meningkatkan laju pembentukan dan pemunculan tunas, yang mana konsentrasi BAP 2,00 mg/L mampu mensintesis sel untuk memacu pertumbuhan tunas. Menurut penelitian Saefas et al.,(2017) kinerja sitokinin eksogen (BAP) dan sitokinin endogen yang di produksi di akar dapat mendukung pertumbuhan tunas dan juga dikatakan pemberian BAP dapat memicu memecahnya seludang tunas dan tumbuhnya mata tunas. Sedangkan waktu muncul tunas terlama terdapat pada perlakuan B0 (kontrol/ Konsentrasi BAP $0 \mathrm{mg} / \mathrm{L}$ ) dengan ratarata waktu muncul tunas 43,40 HST . Hal ini diduga pada perlakuan B0 (kontrol/ tanpa BAP) tunas muncul terlama hal ini dipacu karena tidak adanya tambahan ZPT eksogen sehingga planlet hanya menggunakan sitokinin endogen untuk menumbuhkan tunas.

\section{Jumlah Tunas Anggrek Bulan (Phalaenopsis sp.)}

Dalam multiplikasi jumlah tunas merupakan parameter yang sangat penting untuk diamati. Karena semakin banyak jumlah tunas yang terbentuk maka akan berpeluang untuk menghasilkan bibit dengan jumlah banyak. Kondisi ini menunjukan bahwa telah terjadi pembelahan sel pada planlet yang diberi perlakuan, dimana perlakuan tersebut menunjukan pengaruh dari pemberian BAP.

Hasil penelitian menunjukan terdapat pengaruh pemberian konsentrsi BAP terhadap jumlah tunas planlet anggrek bulan (Phalaenopsis sp.). Secara statistik hasil pangamatan jumlah tunas planlet tanaman anggrek menunjukan hasil yang berbeda nyata. Rata-rata jumlah tunas planlet tanaman anggrek dapat dilihat pada tabel 1 .

Tabel 1. Jumlah tunas anggrek bulan (Phalaenopsis sp.).

\begin{tabular}{cccccc}
\hline \multirow{2}{*}{ Perlakuan } & \multicolumn{5}{c}{ Rata-rata Jumlah Tunas Minggu Ke- } \\
\cline { 2 - 6 } & IV & VI & VIII & X & XII \\
\hline B0 & $0,000 \mathrm{~b}$ & $0,200 \mathrm{c}$ & $0,400 \mathrm{c}$ & $0,400 \mathrm{~b}$ & $0,400 \mathrm{~b}$ \\
B1 & $0,400 \mathrm{~b}$ & $0,400 \mathrm{bc}$ & $1,200 \mathrm{bc}$ & $1,200 \mathrm{~b}$ & $1,200 \mathrm{~b}$ \\
B2 & $1,600 \mathrm{ab}$ & $2,600 \mathrm{ab}$ & $4,600 \mathrm{ab}$ & $5,400 \mathrm{a}$ & $5,800 \mathrm{a}$ \\
B3 & $2,000 \mathrm{a}$ & $3,000 \mathrm{a}$ & $5,000 \mathrm{ab}$ & $7,800 \mathrm{a}$ & $8,800 \mathrm{a}$ \\
B4 & $1,200 \mathrm{ab}$ & $2,200 \mathrm{ab}$ & $5,600 \mathrm{a}$ & $7,200 \mathrm{a}$ & $8,400 \mathrm{a}$ \\
\hline
\end{tabular}

Keterangan : Angka yang diikuti dengan huruf yang sama pada kolom yang sama tidak berbeda nyata pada taraf 5\% dengan uji Tukey. B0 = Kontrol (Tanpa BAP), B1 = BAP konsentrasi 0,50 $\mathrm{mg} / \mathrm{L}, \mathrm{B} 2=\mathrm{BAP}$ konsentrasi $1,00 \mathrm{mg} / \mathrm{L}, \mathrm{B} 3=\mathrm{BAP}$ konsentrasi $1,50 \mathrm{mg} / \mathrm{L}$, dan B4 = BAP konsentrasi $2,00 \mathrm{mg} / \mathrm{L}$.

Pada tabel 1 mengenai rata-rata jumlah tunas anggrek bulan terlihat bahwa terdapat pengaruh dari penambahan beberapa konsentrasi BAP terhadap ratarata jumlah tunas anggrek bulan. Berdasarkan hasil penelitian pada tabel 1 dapat dilihat pertumbuhan jumlah tunas anggrek bulan (Phalaenopsis sp.) pada setiap minggu setelah tanam. Pada minggu ke IV mulai terlihat adanya pengaruh pemberian BAP. Pada minggu ke IV perlakuan B3 (konsentrasi BAP $=1,50 \mathrm{mg} / \mathrm{L}$ ) merupakan perlakuan yang menunjukan pengaruh paling baik untuk parameter pengamatan jumlah tunas anggrek bulan (Phalaenopsis sp.) dengan nilai rata-rata jumlah tunas 2 buah. Hasil tersebut berbeda nyata dengan perlakuan B0 (Kontrol/ tanpa BAP) dan $\mathrm{B} 1$ (Konsentrasi BAP $=0,50 \mathrm{mg} / \mathrm{L})$. Akan tetapi nilai rata-rata jumlah tunas anggrek bulan (Phalaenopsis sp.) pada perlakuan B3 (konsentrasi $\mathrm{BAP}=1,50 \mathrm{mg} / \mathrm{L}$ ) tidak berbeda nyata dengan hasil yang ditunjukan oleh perlakuan B2 (konsentrasi 
$\mathrm{BAP}=1,00 \mathrm{mg} / \mathrm{L}$ ) dan B4 (konsentrasi $\mathrm{BAP}=2,00 \mathrm{mg} / \mathrm{L})$.

Pada minggu ke VI, perlakuan B3 (konsentrasi $\mathrm{BAP}=1,50 \mathrm{mg} / \mathrm{L}$ ) masih menunjukan rata-rata jumlah tunas anggrek bulan paling baik yaitu sebanyak 3 buah. Hasil tersebut berbeda nyata dengan hasil rata-rata yang ditunjukan perlakuan B0 kontrol/tanpa BAP dan B1 (konsentrasi $\mathrm{BAP}=0,50 \mathrm{mg} / \mathrm{L}$ ). Akan tetapi tidak berbeda nyata dengan hasil yang ditunjukan oleh perlakuan B2 konsentrasi BAP 1,00 $\mathrm{mg} / \mathrm{L}$ dan B4 (konsentrasi $\mathrm{BAP}=2,00 \mathrm{mg} / \mathrm{L}$ ).

Minggu ke VIII, perlakuan B4 (konsentrasi $\mathrm{BAP}=2,00 \quad \mathrm{mg} / \mathrm{L}$ ) menunjukkan rata-rata jumlah tunas anggrek bulan (Phalaeonopsis sp.) dengan rata-rata jumlah tunas 5,6 buah. Hasil ini tidak berbeda nyata dengan yang ditunjukkan oleh perlakuan B2 (Konsentrasi BAP $=0,50 \mathrm{mg} / \mathrm{L}$ ) dan B3 (konsentrasi BAP $=1,50 \mathrm{mg} / \mathrm{L}$ ). Akan tetapi nilai rata-rata tersebut berbeda nyata dengan perlakuan B0 (kontrol/ tanpa BAP) dan B1 (konsentrasi BAP = 1,00 $\mathrm{mg} / \mathrm{L})$.

Pada minggu ke $\mathrm{X}$ dan XII menunjukkan hasil yang sama yaitu perlakuan B3 (konsentrasi BAP $=1,50$ $\mathrm{mg} / \mathrm{L})$ merupakan perlakuan yang menunjukan nilai rata-rata jumlah tunas anggrek bulan (Phalaenopsis sp.) paling baik dengan rata-rata 7,8 untuk minggu ke $\mathrm{X}$ dan 8,8 buah untuk minggu ke XII. Hasil tersebut tidak berbeda nyata dengan nilai rata-rata jumlah tunas yang ditunjukkan oleh perlakuan B2 (konsentrasi $\mathrm{BAP}=$ $1,00 \mathrm{mg} / \mathrm{L}$ ) dan B4 (konsentrasi BAP = 2,00 mg/L). Akan tetapi berbeda nyata dengan hasil rata-rata jumlah tunas yang di tunjukan oleh perlakuan (B0 kontrol/ tanpa BAP) dan BI (konsentrasi BAP = $0,50 \mathrm{mg} / \mathrm{L})$.

Berdasarkan hasil olah data yang terdapat dalam tabel 1. secara keseluruhan, rata-rata jumlah tunas terbanyak didominasi oleh perlakuan B3 (konsentrasi $\mathrm{BAP}=1,50 \mathrm{mg} / \mathrm{L}$ ) sehingga perlakuan B3 merupakan perlakuan yang paling optimal pada penelitan ini. Hal ini diduga konsentrasi tersebut merupakan konsentrasi yang sesuai untuk anggrek bulan (Phalaenopsis sp.) melakukan pembelahan sel untuk membentuk tunas. Dimana hormon endogen dan eksogen berada pada titik maksimal sehingga tunas yang di munculkan banyak. Di duga kembali respon yang muncul pada perlakuan B3 (Konsentrasi BAP $=1.50$ $\mathrm{mg} / \mathrm{L})$ memiliki ketergantungan terhadap kemampuan planlet dalam menyerap dan menggunakan zat pengatur tumbuh endogen yang ada dan ZPT eksogen yang diserap dari media tumbuh dengan baik (Tuhuteru et al., (2012). Di alam, tidak satupun unsur yang berdiri sendiri, semua saling berinteraksi antara satu dengan lainnya, begitupun dengan zat pengatur tumbuh seperti sitokinin dapat bekerja dengan bantuan auksin. Menurut Zulkarnain (2009) peranan auksin dan sitokinin sangat nyata dalam pengaturan pembelahan sel, pemanjangan sel dan diferensiasi sel. Apabila pemberian sitokinin lebih tinggi dari auksin maka hal ini akan menstimulus pertumbuhan tunas lebih baik.

Tetapi perlakuan B4 (konsentrasi $\mathrm{BAP}=2,00 \mathrm{mg} / \mathrm{L})$ dan perlakuan B2 (konsentrasi BAP $=1,00 \mathrm{mg} / \mathrm{L}$ ) pada tabel1. memiliki pengaruh tidak berbeda nyata dengan perlakuan B3 (konsentrasi $\mathrm{BAP}=1,50 \mathrm{mg} / \mathrm{L})$. Hal ini diduga pemberian ZPT eksogen pada perlakuan B2 (konsentrasi BAP $=1,00 \mathrm{mg} / \mathrm{L}$ ) dan B4 (konsentrasi BAP $=2,00 \mathrm{mg} / \mathrm{L}$ ) memberikan respon yang sebanding sama dengan perlakuan B3 (konsentrasi BAP = $1,50 \mathrm{mg} / \mathrm{L}$ ) sehingga menunjukan hasil yang tidak berbeda nyata, hal ini diduga ada pengaruh dari planlet yang digunakan. Planlet yang digunakan pada penelitian ini berasal dari hasil inisiasi dan multiplikasi yang dilakukan berulang, sehingga diduga planlet masih membawa kandungan yang berasal dari media sebelumnya sehingga mempengaruhi pertumbuhan akan tetapi jika dilihat rata-rata jumlah tunas yang tumbuh, rata-rata jumlah tunas pada perlakuan B4 (konsentrasi $\mathrm{BAP}=2,00$ $\mathrm{mg} / \mathrm{L})$ berada dibawah rata-rata jumlah 
tunas perlakuan B3 (konsentrasi BAP 1,50 $\mathrm{mg} / \mathrm{L}$ ). Hal ini terjadi diduga karena konsentrasi tinggi yang diberikan justru dapat bersifat sebagai penghambat pertumbuhan sesuai dengan yang dilaporkan oleh Zulkarnain (2009) yaitu penambah zat pengatur tumbuh yang tidak sesuai cenderung menyebabkan terahambatnya regenerasi tunas, dan menurut Kusmianto (2008) penggunaan sitokinin pada konsentrasi tinggi dapat mengganggu penyerapan unsur hara serta menghambat pertumbuhan. Selain itu diduga planlet mengalami kondisi terhabituasi yang disebabkan karena planlet ditanam pada media dan ZPT yang berbeda dengan media awal multiplikasi maka pertumbuhan akan terhambat (Arti dan Mukarlina, 2017).

Pada perlakuan B0 (kontrol/ tanpa $\mathrm{BAP}$ ) dan B1 (konsentrasi BAP 0,50 $\mathrm{mg} / \mathrm{L}$ ) berbeda nyata dengan perlakuan B3 (konsentrasi $\mathrm{BAP}=1,50 \mathrm{mg} / \mathrm{L}$ ) hal ini diduga dengan pemberian BAP pada konsentrasi rendah untuk perlakuan B1 (konsentrasi $\mathrm{BAP}=0,50 \mathrm{mg} / \mathrm{L}$ ) dan tanpa pemberian BAP untuk perlakuan B0 (kontrol/ tanpa BAP) kurang mampu memberikan stimulus pada planlet anggrek bulan untuk melakukan pembelahan sel sehingga laju pertumbuhan tunas anggrek bulan (Phalaenopsis sp.) berlangsung lambat. Selain itu ZPT yang diberikan tidak seimbang dengan hormon yang dibutuhkan oleh planlet tersebut sehingga menghasilkan jumlah tunas yang berbentuk sedikit.
Pertumbuhan tunas pada multiplikasi di pengaruhi oleh keberadaan ZPT (Zat Pengatur Tumbuh). Salah satu ZPT yang terpenting keberadaanya dalam multipliksi adalah sitokinin, menurut Wattimena (2014) Sitokinin dapat mengendalikan pertumbuhan dan pemunculan tunas. Sitokinin eksogen dapat meningkatkan pembelahan sel dan memang dibutuhkan untuk proses tersebut, (Salisbury and Ross, 1995). Untuk mampu menjalankan tugasnya dengan maksimal sitokinin harus diaktifkan oleh bantuan hormon lain yaitu auksin. Auksin dengan aktifnya sitokinin diikuti dengan aktifnya enzim yang menaikan sintesis protein yang merupakan protein pembangun sel sehingga terbentuk sel-sel baru yang pada akhirnya terdeferensiasi menjadi organ tertentu (Kartiman et al., 2018).

\section{Waktu Muncul Daun Anggrek Bulan (Phalaenopsis sp.)}

Daun merupakan organ tanaman yang berfungsi untuk proses fotosintesis. Keberadaan daun sangat penting untuk kelangsungan hidup tanaman, karena daun merupakan organ yang berfungsi sebagai tempat menyimpan cadangan makanan dan juga menyimpan cadangan air. Waktu muncul daun diamati sejak penanaman eskplan hingga daun pertama tumbuh. Menurut hasil yang diperoleh secara statisik, perlakuan pemberian BAP memiliki pengaruh yang nyata terhadap waktu muncul daun. Hasil penelitian tersebut dapat dilihat pada Gambar 2. 


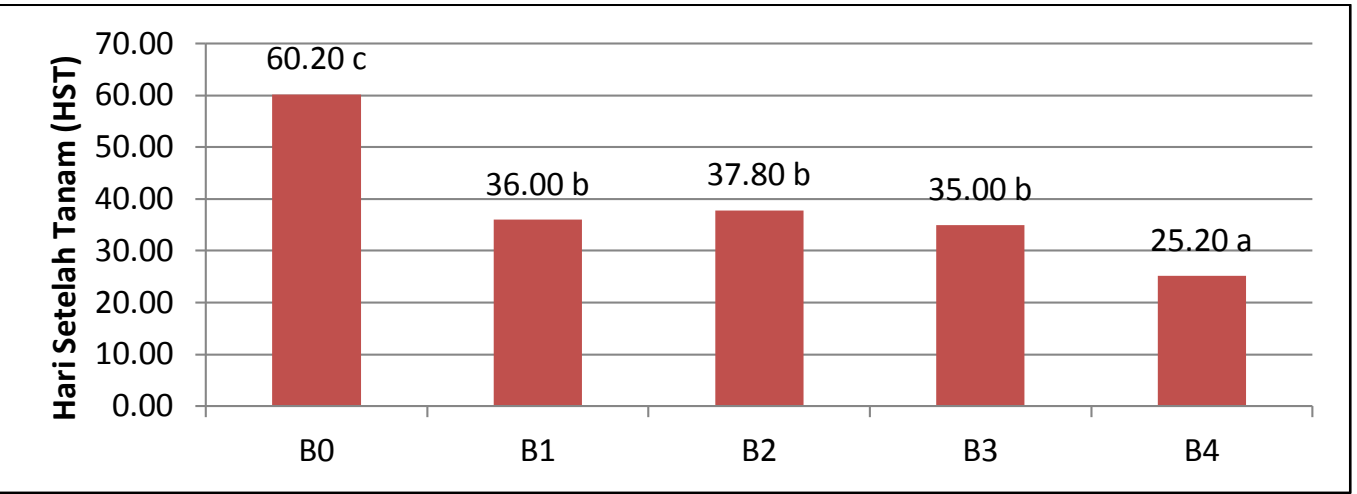

Gambar 2. Waktu muncul daun anggrek bulan (Phalaenopsis sp.).

Keterangan : Angka yang diikuti dengan huruf yang sama pada grafik yang sama tidak berbeda nyata pada taraf 5\% dengan uji Tukey. B0 : Kontrol (Tanpa BAP), B1 : BAP konsentrasi 0,50 $\mathrm{mg} / \mathrm{L}, \mathrm{B} 2$ : BAP konsentrasi 1,00 mg/L, B3 : BAP konsentrasi 1,50 mg/L, dan B4 : BAP konsentrasi BAP 2,00 mg/L.

Berdasarkan gambar 2. terlihat bahwa terdapat pengaruh dari penambahan beberapa konsentrasi BAP terhadap waktu muncul daun. Pada gambar 2. dapat dilihat waktu tercepat muncul tunas terdapat pada perlakuan B4 (Konsentrasi BAP 2,00 mg/L) dengan waktu muncul tercepat dengan rata-rata waktu muncul daun 25,20 HST, berbeda nyata dengan perlakuan B0 (Konsentrasi $\mathrm{BAP}=0 \mathrm{mg} / \mathrm{L}$ ), B1 (Konsentrasi BAP $=$ $0,50 \mathrm{mg} / \mathrm{L}$ ), B2 (konsentrasi BAP $=1,00$ $\mathrm{mg} / \mathrm{L}$ ) dan B3 (Konsentrasi BAP $=1,50$ $\mathrm{mg} / \mathrm{L}$ ). Hal ini diduga pemberian BAP pada konsentrasi $2,00 \mathrm{mg} / \mathrm{L}$ merupakan perlakuan yang seimbang antara ZPT alami (endogen) dan eksogen sehingga sel dapat membelah dengan baik, membesar dan terdeferensiasi menjadi organ daun dengan bantuan dari hormon lain seperti auksin dan giberelin. Hal ini sesuai dengan yang dilaporkan Salisbury and Ross (1995) sitokinin eksogen yang diberikan dapat memacu pembesaraan sel pada daun.
Sehingga konsentrasi BAP 2,00 mg/L mampu memunculkan daun anggrek bulan (Phlaenopsis sp.) lebih cepat dibandingkan dengan konsentrasi lain. Sedangkan waktu muncul daun terlama terdapat pada perlakuan B0 ( kontrol/ tanpa BAP) pada 60,20 HST. Hal ini di duga konsentrasi sitokinin alami (endogen) mencukupi untuk mendorong pertumbuhan daun tetapi sitokinin alami (endogen) tersebut tersedia dalam jumlah kecil sehingga menimbulkan waktu muncul daun, menunjukan waktu terlama.

\section{Jumlah Daun Anggrek Bulan (Phalaenopsis sp.)}

Hasil pengamatan jumlah daun anggrek bulan menunjukan terdapat pengaruh dari pemberian BAP terhadap pertumbuhan daun anggrek bulan. Secara statistik hasil data pengamatan menunjukan hasil yang berbeda nyata. Rata-rata jumlah daun anggrek bulan dapat dilihat pada tabel 2 . 
Tabel 2. Jumlah Daun anggrek bulan (Phalaenopsis sp.)

\begin{tabular}{ccccc}
\hline \multirow{2}{*}{ Perlakuan } & \multicolumn{4}{c}{ Rata-rata Jumlah Daun Minggu Ke- } \\
\cline { 2 - 5 } & VI & VIII & $\mathbf{X}$ & XII \\
\hline B0 & $0,000 \mathrm{c}$ & $0,200 \mathrm{c}$ & $0,600 \mathrm{c}$ & $1,000 \mathrm{c}$ \\
B1 & $0,400 \mathrm{bc}$ & $0,600 \mathrm{bc}$ & $2,000 \mathrm{c}$ & $2,800 \mathrm{c}$ \\
B2 & $2,200 \mathrm{a}$ & $3,800 \mathrm{a}$ & $5,600 \mathrm{~b}$ & $7,200 \mathrm{~b}$ \\
B3 & $1,800 \mathrm{ab}$ & $4,800 \mathrm{a}$ & $8,000 \mathrm{ab}$ & $11,400 \mathrm{a}$ \\
B4 & $2,000 \mathrm{a}$ & $6,000 \mathrm{a}$ & $9,00 \mathrm{a}$ & $14,400 \mathrm{a}$ \\
\hline
\end{tabular}

Keterangan : Angka yang diikuti dengan huruf yang sama pada kolom yang sama tidak berbeda nyata pada taraf 5\% dengan uji Tukey. B0 = Kontrol (Tanpa BAP), B1 = BAP konsentrasi $0,50 \mathrm{mg} / \mathrm{L}, \mathrm{B} 2=\mathrm{BAP}$ konsentrasi $1,00 \mathrm{mg} / \mathrm{L}, \mathrm{B} 3=\mathrm{BAP}$ konsentrasi 1,50 mg/L, dan $\mathrm{B} 4=\mathrm{BAP}$ konsentrasi 2,00 $\mathrm{mg} / \mathrm{L}$.

Berdasarkan tabel 2 terlihat bahwa ada pengaruh dari penambahan beberapa konsentrasi BAP terhadap jumlah daun anggrek bulan. Hasil penelitian pada tabel 2. dapat dilihat penambahan jumlah daun anggrek bulan (Phalaenopsis sp.) pada setiap minggu setelah tanam. Pada minggu ke VI mulai terlihat adanya pengaruh dari penambahan BAP. Pada minggu ke VI perlakuan B2 (konsentrasi $\mathrm{BAP}=1,00$ $\mathrm{mg} / \mathrm{L})$ merupakan perlakuan yang menunjukan pengaruh paling baik untuk parameter pengamatan jumlah daun anggrek (Phalaenopsis sp.) dengan nilai ratarata jumlah daun 2,2 helai. Hasil tersebut berbeda nyata dengan perlakuan B0 (kontrol/ tanpa BAP) dan B1 (konsentrasi $\mathrm{BAP}=0,50 \mathrm{mg} / \mathrm{L})$ akan tetapi, nilai ratarata jumlah daun anggrek bulan (Phalaenopsis sp.) pada perlakuan B2 (konsentrasi BAP 1,00 $\mathrm{mg} / \mathrm{L}$ ) tidak berbeda nyata dengan hasil yang ditunjukan oleh perlakuan B3 (konsentrasi $\mathrm{BAP}=1,50 \mathrm{mg} / \mathrm{L}$ ), dan $\mathrm{B} 4$ (konsentrasi $\mathrm{BAP}=2,00 \mathrm{mg} / \mathrm{L})$.

Pada minggu ke VIII, perlakuan B4 (konsentrasi $\mathrm{BAP}=2,00 \mathrm{mg} / \mathrm{L}$ ) menunjukan rata-rata jumlah daun anggrek bulan paling baik yaitu 6 helai. Hasil tersebut berbeda nyata dengan yang ditunjukan oleh perlakuan B0 (kontrol/ tanpa BAP) dan B1 (konsentrasi BAP= 0,50 $\mathrm{mg} / \mathrm{L})$. Akan tetapi tidak berbeda nyata dengan hasil yang ditunjukan oleh perlakuan B2 (konsentrasi $\mathrm{BAP}=1,00$ $\mathrm{mg} / \mathrm{L}$ ) dan $\mathrm{B} 3$ (konsentrasi $\mathrm{BAP}=1,50$ $\mathrm{mg} / \mathrm{L})$.

Minggu ke $\mathrm{X}$, perlakuan $\mathrm{B} 4$ (konsentrasi $\mathrm{BAP}=2,00 \mathrm{mg} / \mathrm{L}$ ) masih menunjukan rata-rata jumlah daun paling baik dengan hasil 9 helai, hasil tersebut berbeda nyata dengan perlakuan B0 (kontrol/ tanpa BAP), B1 (konsentrasi $\mathrm{BAP}=0,50 \mathrm{mg} / \mathrm{L}$ ) dan $\mathrm{B} 2$ (konsentrasi $\mathrm{BAP}=1,00 \mathrm{mg} / \mathrm{L})$ tetapi perlakuan $\mathrm{B} 4$ (konsentrasi $\mathrm{BAP}=2,00 \mathrm{mg} / \mathrm{L}$ ) tidak berbeda nyata dengan perlakuan B3 (konsentrasi $\mathrm{BAP}=1,50 \mathrm{mg} / \mathrm{L}$ ).

Pada minggu ke XII, perlakuan paling baik masih ditunjukan oleh perlakuan B4 (konsentrasi $\mathrm{BAP}=2,00$ $\mathrm{mg} / \mathrm{L})$ dengan hasil 14,4 helai, hasil tersebut berbeda nyata dengan perlakuan B0 (kontrol/ tanpa BAP), B1 (konsentrasi $\mathrm{BAP}=0,50 \mathrm{mg} / \mathrm{L}$ ) dan B2 (konsentrasi $\mathrm{BAP}=1,00 \mathrm{mg} / \mathrm{L})$ ) tetapi perlakuan $\mathrm{B} 4$ (konsentrasi $\mathrm{BAP}=2,00 \mathrm{mg} / \mathrm{L}$ ) tidak berbeda nyata dengan perlakuan B3 (konsentrasi $\mathrm{BAP}=1,50 \mathrm{mg} / \mathrm{L}$ ).

Berdasarkan rata-rata jumlah daun dari pengamatan minggu ke VI - XII, perlakuan B4 (konsentrasi $\mathrm{BAP}=2,00$ $\mathrm{mg} / \mathrm{L})$ mendominasi rata-rata jumlah daun terbanyak pada setiap pengamatan minggu setelah tanam. Dimana perlakuan B4 (konsentrasi BAP $=2,00 \mathrm{mg} / \mathrm{L}$ ) menunjukan hasil paling baik. Diduga karena BAP merupakan golongan sitokinin, yang mana salah satu tujuan penambahan sitokinin adalah kemampuannya untuk menginduksi terbentuknya organ pokok, selain itu penggunaan BAP dengan konsentrasi tinggi dapat mendorong sel melakukan pembelahan dengan cepat. Hal ini sesuai dengan yang dinyatakan oleh Fereol et al., (2002) yaitu konsentrasi sitokinin tinggi penting dalam pembentukan daun. 
Interaksi dari perimbangan ZPT yang ditambahkan ke dalam media kultur dan yang diproduksi oleh sel tanaman (hormon endogen) menentukan kecepatan dan arah perkembangan suatu kultur (Gunawan, 1992 dalam Arti dan Mukarlina, 2017).

BAP merupakan salah satu ZPT dari golongan sitokinin sintetik. Menurut Salisbury and Ross (1995) mekanisme kerja sitokinin yang terjadi pada tumbuhan memiliki beberapa macam mekanisme kerja dalam jaringan yang berbeda. Sitokinin terdapat dalam konsentrasi sangat rendah. Adanya efek pemacuan oleh sitokinin pada pembentukan RNA dan enzim sudah di duga sejak lama. Pemacuan sitokinensis merupakan salah satu respons sitokinin yang terpenting.

Sitokinin dapat menaikan laju sintesis protein. Beberapa protetin itu berupa protein pembangun atau enzim yang dibutuhkan untuk mitosis. Sintesis protein dapat ditingkatkan dengan cara memacu pembentukan RNA kurir yang menyandikan protein tersebut. Fosket et al.,(1981) dalam Salisbury and Ross (1995) menyimpulkan bahwa sitokinin bekerja khususnya pada proses translasi. Salah satu bukti yang melandasi kesimpulan tersebut adalah bahwa ribosom dalam sel yang diberi perlakuan sitokinin berkelompok dalam polisom pensintesis protein yang protein pembelahan sel. Mereka menunjukan bahwa suatu protein inti menjadi sasaran sitokinin, diduga, protein tersebut memacu pembelahan sel secara langsung. Mereka menemukan juga bahwa benzyladenin sangat mempersingkat waktu berlangsungnya fase $S$ dalam siklus sel, dimana fase $S$ merupakan tahap sintesis RNA yang menghasilkan replikasi DNA yang identik dengan DNA induk. Fase S diikuti oleh fase G2 dimana sel mempersiapkan diri untuk melakukan mitosis, pada fase ini terjadi pembelahan inti dan pemisahan sitoplasma.

Hasil penelitian yang didapatkan sesuai dengan penelitian Ernitha (2005) yang menyatakan pemberian BAP berpengaruh nyata terhadap jumlah tunas yang terbentuk pada planlet tanaman anggrek (Dendrobium sp.) secara in vitro. Selain itu juga pengaruh BAP terhadap multiplikasi juga terlihat pada penelitian Fitriyandini et al., (2015) yang menyatakan bahwa penambahan BAP pada media Murishage and Skoog pada anggrek bulan (Phalaenopsis amabilis) memberikan hasil waktu muncul tunas, jumlah tunas dan jumlah daun terbaik. besar, bukan dalam polisom yang kecil atau sebagai monoribosom bebas.

Pada sistem siklus sel, sitokinin melakukan proses pensinyalan pada tahap mitosis di tahapan interfase. Tahap interfase merupakan tahap yang disebut dengan tahap istirahat dimana pada fase ini sel-sel mempersiapkan diri dengan mengumpulkan energi untuk memasuki tahapan pembelahan sel. Menurut Fosket et al.,(1981) dalam Salisbury and Ross (1995) sitokinin mendorong pembelahan sel dalam biakan jaringan dari tahap peralihan $\mathrm{G}_{2}$ menuju mitosis.

\section{KESIMPULAN}

Berdasarkan hasil penelitian dapat disimpulkan bahwa:

1. Penambahan BAP berpengaruh positif terhadap waktu muncul tunas tanaman anggrek. Pemberian BAP (Bensyl Amino Purine) dengan konsentrasi 2,00 $\mathrm{mg} / \mathrm{L}$ merupakan perlakuan paling baik dengan waktu muncul tunas tercepat 16,80 HST .

2. Penambahan BAP berpengaruh positif terhadap jumlah tunas tanaman anggrek bulan yang dhasilkan. Penambahan BAP dengan konsentrasi $1,50 \mathrm{mg} / \mathrm{L}$ merupakan perlakuan paling baik dengan hasil rata-rata jumlah tunas tanaman 8,8 buah pada minggu akhir penelitian.

3. Penambahan BAP berpengaruh positif terhadap waktu muncul daun tanaman anggrek. Pemberian BAP (Bensyl Amino Purine) dengan konsentrasi 2,00 
mg/L merupakan paling baik dengan waktu muncul daun tercepat 25,20 HST.

4. Penambahan BAP berpengaruh positif terhadap jumlah daun tanaman anggrek. Penambahan BAP dengan konsentrasi 2,00 $\mathrm{mg} / \mathrm{L}$ merupakan perlakuan paling baik dengan hasil rata-rata 14,4 helai daun pada akhir pengamatan yaitu minggu ke XII.

\section{DAFTAR PUSTAKA}

Arti, Lisa., dan Mukarlina. 2017. Multiplikasi Anggrek Bulan Dengan Penambahan Ekstrak Taoge dan Benzyl Amino Purine. Jurnal Protobiont. Universitas Tanjungpura. Pontianak. 6 (3): 278282.

Djajanegara, I. 2010. Pemanfaatan Limbah Buah Pisang dan Air Kelapa sebagai Bahan Media Kultur In Vitro Anggrek. Jurnal Teknologi Lingkungan. 13(3): 373380.

Fereol, L, Chovelon, V, Causse, S, Mihaux - Ferriere $\mathrm{N}$ and Kahane, R. 2002. Evidence Of a somatic Embryogenesis Process for plan regeneration in Garlic (Allium sativum L). Plant cell Rep, 21 : 197-203.

Fithriyandini A, Maghfoer MD, Wardiyati T. 2015. Pengaruh Media Dasar 6Benzylaminopurine (BAP) terhadap pertumbuhan dan perkembangan nodus tangkai bunga anggrek bulan (Phalaenopsis amabilis) dalam perbanyakam secara in vitro. Produksi tanaman. Vol. 3. Hal. 43-39.

Indarto, Novo. 2011. Pesona Anggrek Petunjuk Praktis Budidaya dan Bisnis Anggrek. Cahaya Atma Pustaka, Yogyakarta.

Kartiman, Roni., Sukma, Aisyah, Purwito. 2018. Multiplikasi in vitro Anngrek Hitam (Coelogyne pandurata Lindl) pada perlakuan kombinasi NAA dan BAP. Jurnal Bioteknologi \&
Biosains Indonesia. Institut Pertanian Bogor. 5(1). ISSN 2548-6IIX. Bogor.

Kusmianto J. 2008. Pengaruh thidiazuron tunggal dan kombinasi thidiazuron dan benzyl amino purine terhadap pembentukan tunas dari potongan daun Dendrobium antennatum Lindl secara in vitro. Skripsi. Fakultas MIPA Universitas Indonesia. Depok Jawa Barat.

Martin, KP and J. Madassary. 2006. Rapid In Vitro propagation of Dendrobium bybrids through direct shoot formation from foliar explants and protocrom like bodies. Sci, Hortic. 108: 95-99.

Panjaitan, Ernitha. 2005. Respon Pertumbuhan Tanaman Anggrek (Dendrobium sp.) Terhadap Pemberian BAP dan NAA Secara In Vitro. Jurnal Penelitian. 3(3): 1 45151.

Paramartha, A.I., D. Ermavitalin dan S. Nurfadillah. 2012. Pengaruh Penambahan Kombinasi Konsentrasi ZPT NAA dan BAP terhadap pertumbuhan dan Perkembangan Biji Dendrobium taurulinum J.J Smith secara In Vitro. Jurnal Sains dan Sen.i ITS. 1. (1): 4043.

Saefas, S.A, S. Rosniawaty., dan Y. Maxyselly. 2017. Pengaruh Konsentrasi Zat Pengatur Tumbuh Alami dan Sintetik Terhadap Pertumbuhan Tanaman Teh (Camellia sintensis (L) O. Kuntze) Kloon GMB7 setelah centering. Jurnal Kultivasi. 16(2): 368-372.

Salisbury, F. B and Ross, C. W. 1995. Fisiologi Tumbuban. Jilid 3. Institut Teknologi Bandung. Bandung.

Tuhuteru S, Hehanussa ML, Raharjo SHT. 2012. Pertumbuhan dan Perkembangan anggrek Dendrobium anosmum pada media kultur in vitro dengan beberapa konsentrasi air kelapa. Agrologia. Vol. 1 : 1-12. 
Wattimena, GA. 1998. Bioteknologi Tanaman. Pusat Antar Universitas. Institut Pertanian Bogor. Bogor

Wu, P. H and D.C.N. Chang. 2009. The Use Of N-G-benziladenine of regulate flowering of Phalaenopsis orchids. Hort Tech. 19 (1) : 200-203. Zulkarnain. 2009. Kultur In Vitro Tanaman Solusi Perbanyakan Tanaman Budidaya. Bumi Angkasa, Jambi. 